\title{
Louise em dois tempos: estratégias brasileiras feministas de criação teatralem fluxo de resistência
}

\section{Louise in two times: Brazilian feminist strategies of theatrical creation in resistance flow}

Luciana de Fatima Rocha Pereira de Lyra ${ }^{1}$ 


\section{Resumo}

Tomando como dínamo a jornada artística da paulistana Beatriz Tragtenberg e suas estratégias de ação no teatro, cartografa-se uma linha espiralar que integra dois tempos, no desvelar de experiências por ela engendradas, quais sejam: a constituição do grupo Teatro-Circo Alegria dos Pobres, durante o golpe militar em 1970, e a invenção do espetáculo Pour Louise ou a desejada virtude da resistência, com base na vida/obra de Louise Michel, ativista francesa do século XIX, elaborado ao longo do golpe político entre 2016/2018. Com uma linguagem de caráter poético-memorial, tramada a entrevistas, o artigo intenta pensar sobre a relação entre práticas anarquistas e feministas no teatro como sendas de resistência.

Palavras-chave: Beatriz Tragtenberg; Teatro-Circo Alegria dos Pobres; Louise Michel; estratégias feministas de criação teatral

\section{Abstract}

Taking as a dynamo the artistic journey of the Beatriz Tragtenberg and her strategies of action in the theater, a spiral line that integrates two times, in the unveiling of experiences generated by her: the constitution of the group Theater-circus Alegria dos Pobres, during the military coup in 1970, and the invention of the play Pour Louise or the desired virtue of resistance, based on the life/work of french activist Louise Michel of the 19th century, drawn up during the political coup between $2016 / 2018$. With a language of poetic-memorial character, screened for interviews, the article tries to think about the relation between anarchist and feminist practices in the theater as paths of resistance.

Keywords: Beatriz Tragtenberg; Theater-circus Alegria dos pobres; Louise Michel; feminist strategies of theatrical creation 
Chegou a data de meu encontro com Bia. Por telefone, pouco antes do dia marcado, sua filha Lucila ${ }^{2}$ havia falado que ela estava ligeiramente adoentada, mas que havia confirmado o nosso encontro. Segui. Com leve atraso cheguei entusiasmada à sua casa no bairro de Perdizes, em São Paulo. Foi Dudu, sua antiga e fiel funcionária, que abriu a porta para mim. Pediu-me para esperar um pouco. 'Vou chamar Dona Bia', disse com sua simpatia nordestina indisfarçável.

Sentada à espera, eu podia avistar diversos papéis sobre à mesa, eram diferentes fragmentos de uma peça teatral e num deles o cabeçalho, Pour Louise ou a desejada virtude da resistência. Sorri no canto da boca, seguindo depois o caminho dos olhos. Fitei nas paredes da casa a jornada de teatro e de vida de Beatriz Tragtenberg estampada em retratos históricos, delicadas recordações. Passeei com vagar pelas imagens ali expostas e elas abriam para mim portais para um mergulho na memória.

Num repente avistei o bairro do Bixiga onde nasceu Bia, na década de 1930, vi - Teatro Santana, onde seu pai operário trabalhara no centro da cidade. Também o bairro de Pinheiros, onde ela foi criada, e a faculdade de Letras da Universidade de São Paulo, onde ela passou a participar de grupos de teatro estudantis. Ainda, o casamento, em 1955, com outro ativo militante de esquerda, o filósofo e educador Maurício Tragtenberg ${ }^{3}$, com quem viveu por mais de 40 anos, até sua morte em 1998.

Num segundo fragmento de tempo, vi projetados noutros papéis e noutras fotografias, agora imaginários, as aulas de francês de Bia, seus cursos de teatro, sua militância de inspiração libertária na periferia de São Paulo e a criação, nos anos de 1970, do Teatro-Circo Alegria dos Pobres, com o qual montou, como arguta coordenadora do grupo, os espetáculos: A Pena e a Lei, O Auto da Compadecida, de Ariano Suassuna, Tocar o Impossível Chão (com músicas de Chico Buarque), trabalhando elementos de cordel associados à festa popular e às influências de Antonin Artaud, isso somente para falar de algumas de suas experiências.

As fotos articulavam beijaminianamente os tempos, e como num filme vi também passar os vários espetáculos atuados pela velha senhora, por quem paciente, eu aguardava. Ali vi cruzar a travessia dos olhos imagens de: $A$ Cozinha, de Wesker, com direção de Antunes Filho; Abelardo e Heloísa, de Ronald Millar, com direção de Flávio Rangel; Édipo Rei de Sófocles, com direção de Marcio Aurélio; A Ópera do Malandro, de Chico Buarque, com direção de Luiz Antônio Martinez Corrêa; Mural Mulher, com direção de João das Neves; O Senhor Paul, de Tankred Dorst; Baudelaire, Mãe coragem, de Brecht, O mercador de Veneza, de Shakespeare, todos esses com direção de Sérgio Ferrara; A Louca de Chaillot, de Jean Giraudoux, com direção de Ruy Cortez; Jogo de Damas, de José Eduardo Vendramini, com direção do autor. Também os espetáculos e leituras dramáticas como Bella Ciao, A Colônia Cecília, $O$ Santo Inquérito. E por fim suas participações em telenovelas na TV Tupi e TV Globo, e os teleteatros na TV Cultura.

\footnotetext{
${ }^{2}$ Lucila Tragtenberg é cantora lírica com graduação (1987) e mestrado (1997) em Canto pela Escola de Música da Universidade Federal do Rio de Janeiro. Doutora (2012) em "Processos de Criação" pelo curso de Comunicação e Semiótica da PUC-SP. É professora na Pontifícia Universidade Católica de São Paulo (PUC-SP) nos cursos de Graduação e Extensão.

${ }^{3}$ Maurício Tragtenberg era pesquisador e professor, lecionando na graduação e pós-graduação de universidades como PUC-SP, USP, UNICAMP e da Escola de Administração de Empresas de São Paulo da Fundação Getúlio Vargas (EAESP-FGV). No meio acadêmico, Tragtenberg ficou conhecido como um autodidata e preferia definir-se como um socialista libertário, ao contrário de "anarquista", e radical. Irreverente com relação aos símbolos e às artimanhas do poder autoritário, foi um intelectual independente e crítico em relação à burocracia acadêmica, que desprezava.
} 
Já estava quase a me perder nesta submersão memorial, quando avistei Bia avançando a manquejar ligeiramente, com aquele sorriso irremediável nos olhos e a boca, como sempre, larga de dentes. Cumprimentamo-nos com um longo e afetuoso abraço. Sim, nos conhecemos. Ambas somos atrizes, eu também a havia dirigido na recente Pour Louise ou a desejada virtude da resistência, aquela peça que tinha avistado adormecida a pouco sobre à mesa. Pour Louise tem toda pesquisa e concepção por Bia tramadas e uma dramaturgia minha, a partir da vida e feitos de Louise Michel, feminista francesa do século XIX.

Enfim, a ideia daquele nosso encontro não era somente para conversar sobre aquela nossa peça, mas era regressar no tempo e tecer palavras sobre a trajetória e a obra de Bia, artista paulistana no alto de seus 83 anos, tomando como exemplo, duas diferentes fases e ações suas no teatro. Levemente arrastada pela forte gripe, Bia insistia em falar, lançando seus olhos ao teto perfurando-o até o céu, num processo de rememoração. Sim, a atividade de rememoração é um movimento necessário para despertar novos horizontes, como nos lembra Benjamin (1987, p. 232):

Certamente, os adivinhos que interrogavam o tempo para saber o que ele ocultava em seu seio não o experimentavam nem como vazio nem como homogêneo. Sabe-se que era proibido aos judeus investigar o futuro. Ao contrário, a prece se ensinava na rememoração. Para os discípulos, a rememoração desencadeava o futuro, ao qual sucumbiam os que interrogavam os adivinhos.

Mas antes de costurar nossas conversações em fios da memória, Bia se inclinou pegando forte a minha mão, indicando que algo muito feliz ali acontecia, afinal, estávamos juntas mais uma vez. Em estado de sororidade alcançava-se a dimensão da confiança, livres podíamos vagar pelo labirinto do tempo e, sem qualquer alarme, disparei a primeira pergunta:

EU: Como se deu a constituição, a formação do Teatro-Circo Alegria dos Pobres? Onde isso aconteceu?

BIA: Eu havia, em 1974, terminado o meu curso de Mestrado na USP, onde aprofundei o estudo da pedagogia Freinet, que era uma pedagogia voltada para o desenvolvimento da personalidade do aluno, para o povo e com o objetivo explícito de mudança social e política. Havia um movimento Freinet internacional, ao qual me filiei neste momento. As escolas de todos os países tinham classes tradicionais e classes Freinet, onde a pesquisa e o profundo desejo de conhecer era o motor das técnicas Freinet. Como até hoje as mudanças de uma pedagogia renovada era um privilégio de escolas ricas e Célestin Freinet fazia questão de que sua escola fosse uma escola para os pobres, uma escola pública. Desejosa de aplicar esta metodologia, encontro minha disciplina de Francês, sendo excluída do currículo escolar. Eu era professora na escola de ensino secundário Virgília Rodrigues Alves de Carvalho Pinto, no Alto da Previdência, perto do Butantã. E eu, por ser efetiva, devendo dedicar todas as minhas horas à escola, desenvolvi então, um leque de atividades culturais: visitas a museus, idas ao cinema e ao teatro, formação da biblioteca, de um cineclube e de um grupo de teatro. Naquele momento, vivíamos uma ditadura terrível e uma descoberta dos professores efetivos que formavam a congregação da escola, de que podiam eleger o seu diretor, em um cochilo da ditadura, que não extinguiu o poder desta congregação. Assim, nós, que por dez anos sofremos situações indignas de expulsão de dois diretores enviados pela Regional da Secretaria da Educação, por abuso sexual de meninas e roubo do pouco dinheiro da Associação de Pais e Mestres, pudemos 
eleger Adibe Abujamra, irmã de Antônio Ambujamra (diretor de teatro). Ela era professora de Educação Física, mas, fato pouco comum entre os professores de Educação Física da época, era culta, politizada e desejava, apesar de estar em fim de carreira, fazer um bom trabalho para os estudantes. E aí surgiu a minha oportunidade, eu era atriz de carreira já há um bom tempo e muito amiga dela, e fazia parte de um pequeno grupo de professores que desejavam arejar e abrir a nossa escola. E ela realmente se transformou. A liberdade e as atividades de nossa escola ficaram famosas em São Paulo. O grupo de teatro (dos alunos da noite) era uma das atividades que eu supervisionava, que era gerido por um jovem jornalista recém-formado, Arthur Cidrin Neto, que havia sido contratado, a meu pedido, pela Associação de Pais e Mestres, para dirigir o grupo. E ele dirigiu a peça A Pena e a Lei, de Ariano Suassuna. No ano seguinte, ele trouxe dois colegas profissionais de teatro, para dirigir um grupo no período da manhã e da tarde, com a peça $O$ Auto da Compadecida de Ariano Suassuna. Fizemos muitas apresentações destes espetáculos na escola Equipe, que iniciava também um momento famoso de atividades teatrais e musicais. Nestes dois anos destes dois grupos, eu os supervisionava, até que os diretores se afastaram e quase que os grupos se extinguiram. ${ }^{4}$

Ouvir Bia era como se todo o contexto histórico de 1970 voltasse à minha própria rede de memórias. Nasci nesta conturbada década e tudo que a ela pertence passou a ser alvo de meus interesses. Lembro de ter lido o livro Cem anos de teatro em São Paulo (1875-1974), de Sábato Magaldi e Maria Thereza Vargas (2000), na Universidade Federal de Pernambuco (UFPE), onde fiz minha graduação em Artes Cênicas. Durante a leitura, no sentido de traçar paralelos entre o teatro paulistano e pernambucano para a aula de Teatro Brasileiro, percebi que a década de 1970, em especial para São Paulo, foi de grande consolidação da indústria cultural em meio ao contraditório recrudescimento da ditadura militar. Importante lembrar, que em oposição à crise mundial do petróleo, o Brasil continuava vivendo o milagre econômico. A indústria cultural já era parte da vida dos paulistas àquele tempo, assim várias escolas de comunicações e artes estavam se consolidando no cenário nacional, como a própria Escola de Arte dramática (EAD/USP).

Exatamente com mais dinheiro circulando, os incentivos ao teatro profissional e ao teatro amador crescem, assim como aumenta o número de festivais de teatro, também os cursos para profissionais e amadores. Naturalmente com maior investimento, a participação de estudantes e entidades culturais no teatro amador tendia a majorar cada vez mais, o que reforçava a contradição, pois enquanto o teatro paulista demonstrava sinais de amadurecimento artístico, a ditadura militar cerceava o momento mais criativo do teatro, e ainda que criassem todos os meios de fugir da censura, o teatro sofreria bastante as consequências deste período.

O lócus do teatro amador, inevitavelmente habitado pelos estudantes havia três principais metas na jornada teatral: a sociabilidade, a comunicação, mas também o escape do golpe e da ditadura militar que ocorria no país, ou seja, os grupos amadores adquiriram a dimensão de espaço de organização cultural com um caráter político, onde os jovens se reuniam para também discutir a situação do país. É fato que o ambiente não era propício para reuniões de grupos, assim o teatro tornava-se uma desculpa para o encontro de pessoas. Os estudantes passaram a utilizar locais subsidiados pelo governo

${ }^{4}$ Todos os fragmentos de entrevistas estão referenciados na bibliografia como Tragtenberg, 2018. 
para promoção de suas atividades, muitas vezes era nas próprias escolas que os grupos faziam o teatro. Alguns grupos amadores e independentes criaram suas próprias sedes culturais, e muitas vezes estes espaços eram localizados nas periferias da cidade, por serem afastados dos centros de atenção do regime, por terem um valor inferior aos do centro e possibilitarem um trabalho junto às comunidades (Magaldi; Vargas, 2000).

Aquele lapso de memória destampado pelo relato inicial de Bia me fez trafegar para o contexto mais amplo do teatro amador paulista e brasileiro no período subsequente ao golpe de 1964, mas o entusiasmo de sua experiência rapidamente me trouxe de volta para o recorte que ali se transfigurava em sua vívida contação. Bia é assim, fustiga a tocar fundo no tempo. No entanto, sem se enredar nas próprias recordações, continuou:

BIA: Foi então, nestes idos de 70, que eu resolvi assumir, definitivamente, a coordenação da peça A Pena e a Lei, que era dos estudantes do curso noturno, que mais necessitavam deste trabalho. Havia muita dificuldade em trabalhar com o período da manhã e o da tarde, porque os pais destes jovens eram pessoas que não compreendiam o quanto de amadurecimento e autonomia, seus filhos adquiriam com a itinerância do grupo, isto é, apresentações em outras escolas, outras cidades. Nosso bairro, que tinha sido criado para os jornalistas, pelo Instituto de Previdência do Estado, não puderam continuar nele devido à distância do bairro de seus locais de trabalho, os jornais e muitas casas do bairro foram dadas como prêmio para informantes da polícia. Uma ocasião, num ensaio da peça, uma aluna do período da tarde, me pediu que não se jogasse no chão, como o seu personagem o cangaceiro, teria que fazer. Eu disse que tudo bem mas perguntei porque, ela respondeu: você não repare, mas meu pai é muito ignorante e quando ele chega em casa ele quer bater em todo mundo e a primeira coisa que a gente faz é esconder o revólver dele. Ele me deu uma surra de cassetete e eu estou todinha dolorida. Por essa razão, optei pelo noturno.

EU: Li outro dia num livro de história do teatro que a partir da década de 1960 o número de grupos amadores estudantis aumentou significativamente e adquiriu uma enorme relevância no cenário de combate à repressão exercida pelo governo ditatorial militar. Foi também por isso que se mobilizou para formar este grupo? Quem eram os participantes?

BIA: Como disse antes, eu estava em 1974, como professora de francês, que havia então caído do currículo escolar, na escola de ensino secundário Virgília Rodrigues Alves de Carvalho Pinto, no Alto da Previdência, perto do Butantã. Como o francês caíra, eu precisava ter uma atividade na escola e então me dediquei às atividades culturais. Quis realizar atividades culturais porque ali onde eu estava o vazio cultural era completo, mesmo com este crescimento do teatro amador. Eu assumi o grupo de teatro porque esta era minha qualificação maior como profissional, pelo meu amor a este ofício e também pela importância do teatro, com o embasamento da Pedagogia Freinet, no desenvolvimento das potencialidades dos alunos. Os participantes eram os alunos de toda a escola que se propunham, voluntariamente, a integrar o grupo, chamados por uma divulgação que fizemos, a qual não discriminava período ou mesmo escola. Eu permitia que alunos do bairro ou de outras escolas do bairro, participassem do grupo. Este fato ficou famoso na região porque dentro do espírito da pedagogia tradicional, só deveriam participar das atividades da escola, os alunos da nossa escola. Em Osasco, o jovem Mario Campos que estudava violão clássico há 6 anos já, ouvira falar do movimento e veio. Hoje ele é professor de música na UNICAMP. Outro jovem, percussionista, sonhava com uma tumbadora e morava no Jabaquara. Também passou a integrar o grupo e ganhou a sua tumbadora. Ele esteve conosco até os últimos anos do Teatro-Circo e depois foi trabalhar com balé, sendo músico de escolas de balé. Os alunos eram, em geral, do período noturno, e eram pobres da periferia circundante à escola. Trabalhavam de dia e estudavam de noite. 
EU: Gostaria de entender como eram as suas práticas no Teatro - Circo Alegria dos Pobres? E também, o porquê deste nome?

BIA: A principal prática da Pedagogia Freinet era a pesquisa que o aluno desenvolvia segundo o seu interesse. Então, desde o momento em que nos sentávamos em círculo, se iniciava uma prática de absoluta liberdade de discussão, de ajuda mútua e de decisões coletivas, contrariamente aos "teatrinhos" que eram feitos nas escolas, onde havia a eleição dos "protagonistas" (que, mantendo uma hierarquia, tinham tratamento diferenciado dos coadjuvantes). Depois de ter sido escolhida a peça pelo coletivo, cada aluno se engajava na tarefa que desejasse realizar: atuação, cenografia, figurinos, música, produção. E eles poderiam também, participar de mais de uma tarefa. Todos os passos eram decididos por todos. Desde a escolha da peça até os locais onde ela seria apresentada, tudo era discutido e decidido por todos, em eleição. De início, nos dois primeiros anos, o grupo se chamava teatro da Escola Estadual de $1^{\circ}$ e $2^{\circ}$ Graus Virgília Rodrigues Alves de Carvalho Pinto e foi registrado no cartório com este nome pois, na época a censura não permitia a realização de nenhum espetáculo dentro ou fora da escola, sem a sua autorização. Neste momento tínhamos ido assistir a trabalhos de teatro profissional de cordel (dramatização) e o espetáculo Viva o Cordão Encarnado, dirigido por Luís Mendonça, para um texto de Luiz Marinho, que trazia o popular Pastoril nordestino, em que participavam as jovens principiantes Elba Ramalho e Tânia Alves. Foi uma paixão geral e um desejo de contribuir naquele momento de valorização da cultura nordestina. O circo estava praticamente se extinguindo e nós sabíamos que alguma coisa tinha que ser feita para que ele não terminasse. Como homenagem ao circo, que também tinha o seu teatro, e que também era uma manifestação popular (praticamente extinta), uma parte do grupo quis citar este Teatro-Circo e o próprio Arthur Cidrin Neto que havia voltado ao grupo, propôs Teatro-Circo Alegria dos Pobres. Havia, porém, uma ala do grupo, mais intelectualizada, sintonizada também com todos os movimentos culturais, de reação à ditadura da época, propôs o nome Grupo de Teatro Alternativa. Feita a eleição do nome, com estes dois nomes propostos, ganhou o Teatro-Circo Alegria dos Pobres, que vinha dos alunos que eram mais pobres, de bairros mais populares da periferia.

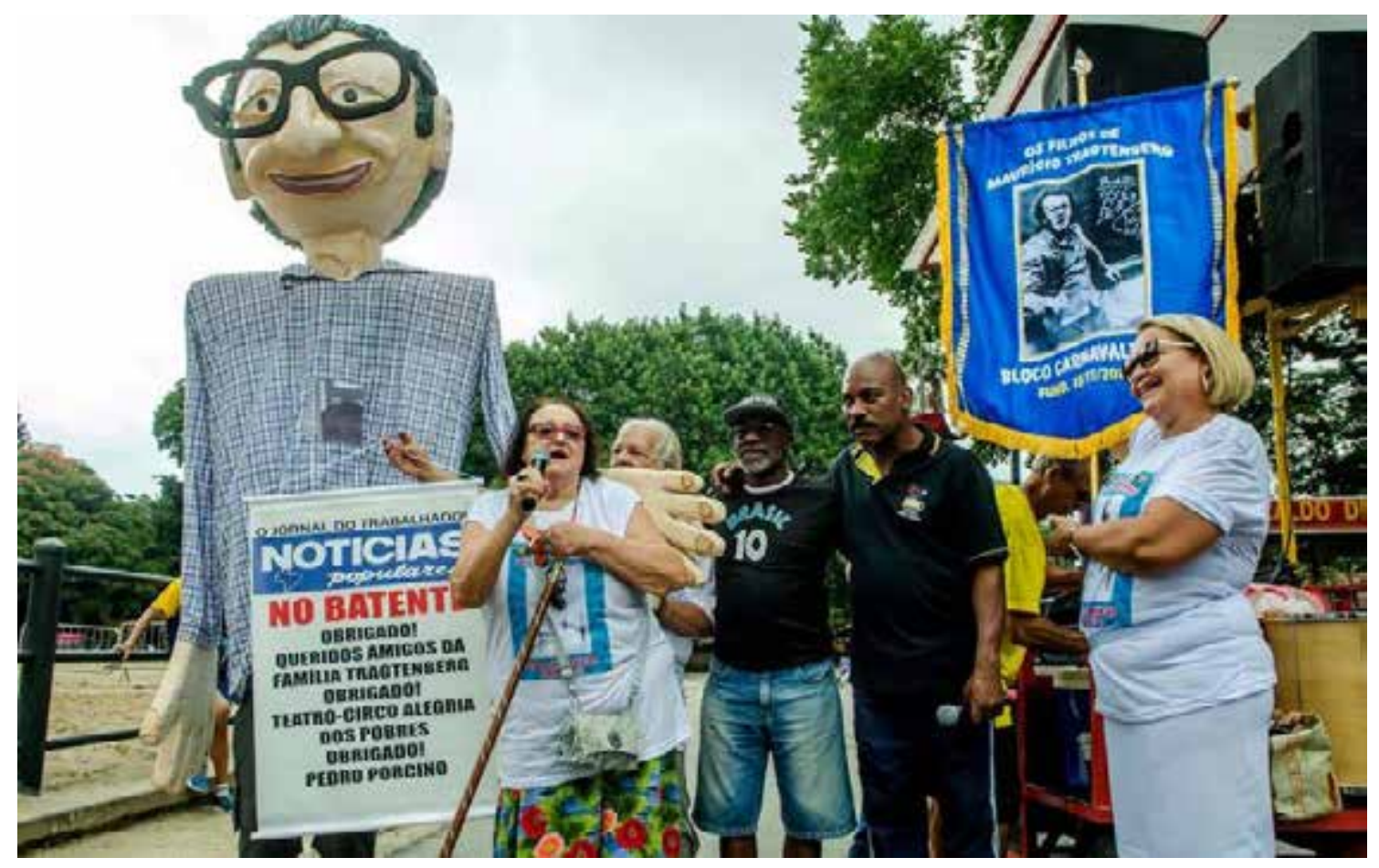

Figura 1 - Homenagem a Maurício Tragtenberg, por ex-integrantes do Teatro-circo alegria dos pobres, no carnaval de 2018. Imagem disponível na Agência de notícia de jornalismo da PUC/SP (http://agemt.org/?=9511). Ao microfone Beatriz Tragtenberg. 
Mais uma vez, ao ouvir os cantos da memória de Bia, abri os cantos da minha. Foi também durante as minhas curiosidades de estudante de artes cênicas em Recife, que ouvi falar de Célestin Freinet (1896-1966). Sua proposta de educação popular se articulava sobremaneira com a ideia de pedagogia para autonomia do meu conterrâneo Paulo Freire (2005), e nos corredores da faculdade de educação da UFPE, em fins dos anos noventa, onde eu cursava as disciplinas voltadas para minha licenciatura, deles muito se falava.

Educador francês do início do século XX, Freinet possuía similaridades com o discurso freiriano, no sentido do favorecimento da educação para todas as classes, pautadas em bases sociais comuns. Ele buscou em sua trajetória de vida proporcionar aos alunos da França, uma escola na qual a democracia se assentava numa perspectiva psicopedagógica, situando o conhecimento de modo coerente, com a meta de adquirir uma ampla compreensão sobre os variados processos inerentes ao aprender humano através da ação educativa. A ideia era educação fundamentada na autogestão do conhecimento, com caráter não diretivo, onde a escola deve ser espaço aberto de construção de autonomia, de expressão, de criatividade e de comunicação do sujeito que pensa, age, constrói e reconstrói seu conhecimento.

Dezoito anos depois de minha formatura e agora absolutamente imersa em questões feministas nas artes da cena, percebo que esta dupla revolução Freinet/ Freire, França/Brasil, dialoga sobremaneira com modelos feministas de educação, que, em geral, propõem um conjunto de estratégias e procedimentos que rompem com a lógica de que o saber se encontra apenas naquele que é fonte de autoridade e transmissor único de conhecimento.

Assim como Freinet/Freire, as pedagogias feministas fomentam a valorização das várias vozes, sendo o diálogo sua dinâmica problematizadora, no qual todas e todos são igualmente falantes e ouvintes, capazes de expressar diferentes saberes. As situações de aprendizagens são especiais momentos nos quais todas/os são levadas/ os a construírem conhecimentos de forma cooperativa (Louro, 1997). Nesta perspectiva, educandas e educandos passam a acreditar em seus saberes, dando sentido às suas falas e aos seus desejos. As pedagogias feministas pretendem ser emancipatórias porque possibilitam a conscientização, em interlocução direta com a libertação e a transformação das/os sujeitas/os e de sua realidade, o que se aproxima sobremaneira das pedagogias freinetianas e freirianas.

Justamente ancorada na perspectiva da pedagogia do oprimido, pensada por Paulo Freire (2005) e fundamentalmente vinculada às práticas do Teatro do Oprimido, de Augusto Boal (2011), a pedagogia feminista do Teatro da Oprimida, vem por exemplo trabalhar com o objetivo de expor, analisar e propor alternativas às opressões vividas pelos grupos diferentes de mulheres por meio do exercício de um sistema de jogos teatrais. Criado em 2009 por Alessandra Vannucci (italiana, professora na PUC do Rio de Janeiro) e Bárbara Santos (brasileira, diretora e atriz em Berlim), o projeto "Laboratório Madalena" abriga as práticas do Teatro da Oprimida. Nas palavras delas:

Nosso ponto de partida foi o corpo feminino, este que passou por mudanças radicais, permanecendo na coxia ao longo de séculos, protegido ou censurado pelo corpo masculino e que hoje parece protagonizar a ribalta da sociedade midiática e do nosso imaginário. Corpo despido, exibido, sensual ou trivial, reinventado, 
espremido e despedaçado nos outdoors, nas páginas das revistas, nas passarelas da moda e do samba. Corpo que se tornou o melhor veículo para venda de qualquer produto e no qual se trava o embate entre cultura (contemporânea e/ou ancestral) e direitos humanos fundamentais. O programa que desenvolvemos teve como proposta a experimentação. Encaixamos ideias e exercícios de construção de cena e de personagem, tirados de nossos percursos, no teatro profissional como diretora e na pesquisa da Estética do Oprimido como Curinga ${ }^{5}$. Criamos um caminho em aberto, deixando coisas por descobrir, por isso "laboratório" e não "oficina". A partir da pesquisa temática e de imagens, desenvolvemos dinâmicas que investigassem perguntas essenciais: quais modelos ancestrais ainda agem no "ser mulher" hoje? Quais contextos sociais condicionam o comportamento e o corpo desse ser mulher? Quais lugares ocupamos e quais queremos ocupar? Quais expectativas, quais sonhos? Quais alternativas? (Santos; Vanucci, 2010)

Vê-se por esta experiência modelar que além de libertadora, transformadora e dialógica, as práticas educativas feministas como o Teatro da Oprimida e outras devem dar poder às mulheres de forma a permitir a "superação" do estado de submissão, discutindo os jogos de poder para que se instaure uma prática educativa definitivamente não-sexista (Louro, 1997, p. 119).

Também neste contexto das práticas feministas em educação é importante lembrar que no século anterior a Freinet e Freire, Louise Michel, educadora, filósofa, escritora, anarquista, que teve protagonismo na construção da Comuna de Paris e criadora do grupo 'O direito da mulher', já atuava nas suas aulas a jovens francesas à maneira autogestionária. Fala-nos Vedovato Júnior (2015, p.110):

Louise Michel conjuga, na construção de sua obra, o que poderíamos chamar (por falta de um termo melhor) um engajamento prático, que compreende desde a sala de aula até o próprio combate armado, com um engajamento intelectual, em sua poética, em seus romances, na discussão política, em publicações em jornais etc. Durante os processos e depois da Comuna de Paris, ficou conhecida como a "Virgem vermelha" ou a "Loba Louise"; pelos movimentos sociais, por outro lado, é sempre lembrada como aquela que empunhou a bandeira negra anarquista pela primeira vez, durante a década de 80 do século XIX, quando se declarou anarquista, após seu exílio na Nova Caledônia; bem como a mulher que escreveu uma série de hinos e poemas relacionados à Comuna e à militância como um todo.

Preocupada com a educação infantil, Michel lecionou alguns anos em Paris até 1856. Aos 26 anos nessa mesma cidade já era autora de uma extensa obra literária, política e educacional com foco nos movimentos sociais revolucionários. Sobre Louise, informa-nos ainda Maria Amélia Teles (2003, p. 38):

Louise Michel (1830-1905), filha de uma servente, começou sua vida de rebeldia ao negar prestar juramento a Napoleão III. Participou da Comuna de Paris em 1871 e foi condenada a dez anos de exílio, depois de ter declarado em juízo: "Pertenço inteiramente à revolução social".

Ativista nas causas feministas, Amelinha (Rago, 2015), como muitos conhecem a autora da supramencionada citação, inclui Louise Michel como importante influência externa

\footnotetext{
${ }^{5}$ Curinga é a terminologia criada por Augusto Boal no Teatro de Arena de São Paulo, na década de 1960 para um criativo sistema de atuação onde atores e atrizes se alternavam pelos personagens. Em seguida passou a utilizar o mesmo termo para identificar o praticante de seu método - Teatro do Oprimido, que tinha a função de estimular o diálogo teatral nas sessões de Teatro-Fórum.
} 
para os movimentos feministas brasileiros no século XIX e nos séculos subsequentes. Certamente por sua libertária ideia de construir um campo de autonomia e autogestão em sua época de violência e iniquidades, Louise também tenha chegado à Bia.

EU: Quando você encontrou Louise na sua trajetória? Quando e como aconteceu o processo com a Louise?

BIA: A Louise, desde sempre a conheci. Aos vinte e poucos anos, estudando a Comuna, me apaixonei tanto pela Comuna, como por esta figura notável de mulher, que já em 1870, criara uma Liga Feminista em Paris. Sempre desejei fazer esta personagem, digo que faz quarenta anos deste desejo. Em 2001 quando houve um seminário em todas as universidades do país, pela passagem dos 130 anos da Comuna de Paris, eu fui convidada pelo grupo da USP e da UNICAMP (que organizavam o evento), para realizar um evento artístico e sem sombra de dúvidas, aceitei. Embora recém operada, sem poder me locomover muito, pelo telefone montei um belíssimo espetáculo que foi feito em São Paulo no Teatro João Caetano. A Orquestra Sinfônica da UNICAMP abriu o espetáculo com a Internacional cantada por Lucila Tragtenberg e depois, se apresentou junto com a Orquestra, o coral da UNICAMP, de quarenta membros, com as músicas específicas da Comuna de Paris. O espetáculo foi apresentado por Sergio Mamberti, o cenário foi criado por Daniela Thomas, muitos grupos de teatro popular participaram (como o Teatro União e Olho Vivo, ainda existente), poetas como Haroldo de Campos e professoras como Margareth Rago que fez brilhantemente, a figura de Louise Michel lendo um texto dela. Enfim, eu estava também comemorando a minha amada Comuna de Paris. Os dois livros que foram editados, com as palestras acadêmicas deste evento, são muito importantes porque contemplam a maior parte das descobertas atuais sobre as realizações da Comuna, que ficaram escondidas à sete chaves, na Bibliothèque Nationale de Paris. Em 2011 se repetiu na PUC-SP, homenagem aos 140 anos da Comuna de Paris e no espetáculo artístico participante do evento, minha amiga Margareth Rago estava no exterior e eu resolvi fazer a Louise Michel. Ao terminar a performance que fiz, fui tomada de profunda emoção com a avalanche de jovens que me cercou, interessadíssimos na figura da Louise, e eu pensei, é agora ou nunca mais. E comecei a pesquisa da Comuna e de Louise. Busquei as Memórias (Mémoire) da Louise, que estavam na Bibliothèque Nationale de Paris. Consegui encontrar também sua correspondência com Victor Hugo, algumas biografias sobre ela, seu livro das Lendas Canaques, a história que ela escreveu (como participante) sobre a experiência da Comuna de Paris. Esta história da Comuna foi o resultado de uma grande pesquisa que a própria Louise fez, nos jornais de oposição e em tudo o que se apresentou a ela como fonte de informação sobre o que aconteceu. Trata-se de uma pesquisa realizada por Louise, com muita competência. Basicamente, para a realização do espetáculo Memórias de Louise, as bases de seu texto foram extraídas por mim e Hélio Muniz, selecionados dos livros Mémoires e História da Comuna de 1871 de Louise Michel, e dos livros de pesquisadores franceses e brasileiros, sobre a história da Comuna de Paris. Este espetáculo foi realizado como uma leitura dramática com cenário e músicos, em várias cidades (Joinville, Curitiba, Florianópolis, São Paulo), com direção de Helio Muniz. Posteriormente, o texto da peça serviu de base para a dramaturgia que foi realizada por você, criando um texto menos acadêmico e mais poético, intitulado Pour Louise ou A Desejada Virtude da Resistência. Você foi também, a diretora da peça que foi apresentada em abril de 2018 no espaço da Cia. Do Latão em São Paulo. Milagrosamente chegamos à elaboração da peça em ensaios das músicas e da encenação, devido à sua generosidade de diretora e dramaturga e de todas e todos os jovens envolvidos na montagem. A montagem se deveu também à generosidade dos amigos e das pessoas que contribuíram financeira e produtivamente, pelo programa de apoio solidário (Catarse), que nos permitiu ter o mínimo de cenário, figurinos e gastos com produção e uma ajuda de custo aos participantes. A todas elas e todos eles, sou profundamente grata: Luciana Lyra, Lucila Tragtenberg, Mariana 
Mayor, Paulinho Brandão, Paulinho Tó, Larissa Galvão, Clara Figueiredo, Laura Andreato, Érika Rocha, Jorge Ferreira Silva e Natalia Siufi. Meus agradecimentos também à Cia do Latão, incluindo seu diretor, Sergio de Carvalho que nos recebeu de braços abertos, com muita generosidade e apoio.

Ao dizer da criação da peça Pour Louise ou a desejada virtude da resistência, Bia me fez lembrar de como nos conhecemos, em São Paulo, no ano de 2016. Recordo de um telefonema de Alessandra Leão ${ }^{6}$, uma grande parceira de trabalhos artísticos. Musicista de formação popular, Alê, como a chamo carinhosamente, disse que estava em contato com João Tragtenberg7, também músico e recém chegado em Recife, advindo de Florianópolis. Disse também que havia encontrado João em sua visita a São Paulo, disse ainda que João estava com sua avó atriz e que todos celebravam a vida numa casa noturna. O fato é que em meio ao encontro, o neto, sempre afetuoso, apresentou sua Bizuca ${ }^{8}$ a minha amiga, que se encantou com sua conversa festiva e eloquente, e mais, que percebeu que os futuros desejos da atriz senescente em melhor elaborar sua Louise no teatro se conectava com minhas pesquisas sobre mulheres guerreiras.

Compreendendo a natureza enredada e mágica das conexões feministas, marquei com Bia um café, fomos juntas assistir ao Teatro Oficina ${ }^{9} \mathrm{e}$, entre cacildas, reis da vela, deliciosos almoços de domingo, conversas intermináveis, tornamo-nos aliadas pela arte, pour Louise, e, em muitas medidas, pelos gritos às causas feministas e sociais. Faz-se necessário lembrar que ao estabelecer aquela nossa aliança, em 2016, não sabíamos o quanto Louise poderia ser importante nas reflexões do duro período que seguiria. Foi no mesmo ano em que nos conhecemos que estourou o golpe de Estado parlamentar pseudolegal. Um golpe de políticos, que mesmo profundamente envolvidos em casos de corrupção, instituíram um processo de destituição contra a presidenta pretextando irregularidades contabilísticas para cobrir défices nas contas públicas.

Lembro ainda que em abril deste ano de 2018, passado impeachemant de Dilma Rousseff, a presente advertência de prisão do ex-presidente Lula, a recém execução aterradora da vereadora Marielle Franco e sob a ameaça de um governo totalitário, estreamos Pour Louise ou a desejada virtude da resistência, na sede da engajada Companhia do Latão ${ }^{10}$, em São Paulo. À época escrevi no programa para do espetáculo:

Num país onde nós mulheres somos mortas e violadas a cada treze minutos, é evidente que o exercício do discurso político seja a nós negado e que a destreza do pensamento e da poética seja a nós restrita. E quando falamos das mulheres que tiveram a dádiva de envelhecer, esse quadro se agrava. No lugar da sábia, da

\footnotetext{
${ }^{6}$ Compositora, cantora e percussionista, nascida em Pernambuco. Foi uma das integrantes/fundadoras da banda Comadre Fulorzinha. Em 2006, inicia sua carreira solo com CD "Brinquedo de Tambor", em 2009, lança o CD "Dois Cordões" e mais recentemente a trilogia de EPs "Língua": composta pelos EPs "Pedra de Sal" (2014), "Aço" (2015) e "Língua" (2015). Entre esses discos, também lançou os CDs dos projetos: "Folia de Santo" (2008) e "Guerreiras - Trilha Sonora Original" (2010).

${ }^{7}$ Musicista, produtor musical, pesquisador industrial na UFPE e Instituto SENAI de Inovação para Tecnologias da Informação e Comunicação.

${ }^{8}$ Apelido de Beatriz Tragtenberg entre seus familiares próximos.

${ }^{9}$ O Teatro Oficina Uzyna Uzona, simplesmente Teatro Oficina, é uma companhia de teatro do Brasil, localizado em São Paulo na rua Jaceguay, bairro do Bixiga. A companhia foi fundada em 1958 na Faculdade de Direito da Universidade de São Paulo por Amir Haddad, José Celso Martinez Correa e Carlos Queiroz Telles.

${ }^{10} \mathrm{~A}$ Companhia do Latão é um grupo teatral de São Paulo, Brasil, interessado na reflexão crítica sobre a sociedade atual. Seu trabalho inclui espetáculos, atividades pedagógicas, edições, bem como uma série de experimentos artísticos. Dirigida desde sua origem por Sérgio de Carvalho, o grupo tornou-se uma referência para o teatro de São Paulo no que se refere à pesquisa estética avançada e à politização da cena.
} 
conselheira da tribo, da curandeira, transfigura-se a encanecida que se deve recolher do convívio social, alocar-se em funções do doméstico da vida. Realmente, em nosso contexto de mundo globalizado e capitalista, não se espera que uma mulher, especialmente em anos avançados, continue a enfrentar o palanque, a ágora, a empunhar a palavra, o gesto, a se arriscar na audácia criativa do teatro. Mas o teatro, que é alquímico, rejuvenescedor e transgressor como as mulheres, pulsa nas veias de quem foi por ele abocanhado e a astúcia das artistas avança selvagem a cada tablado no sentido do grito. Assim sucedeu-se com Beatriz Tragtenberg. Enfrentando as barricadas da escassez de recursos públicos para as artes, as trincheiras da passagem do tempo, resolveu enfrentar uma linda aventura, digamos, 'arqueológica', no desencavar da figura de Louise Michel, combatente gloriosa da Comuna de Paris, do século XIX, projetando-a para a cena. E foi justamente portando a máscara ritual de Louise, que Bia me chegou. Com entusiasmo de menina em festa, com sua vasta experiência teatral e política, habitando seu grande coração. Convocou-me como quem alista mais uma guerreira para a luta e era inevitável não entrar nesta peleja. Passei a tramar a dramaturgia de POUR LOUISE ou A DESEJADA VIRTUDE DA RESISTÊNCIA, a desaguar na sua encenação. Mas o exército ainda não estava completo, precisávamos arregimentar outrxs tantxs jovens soldados d'Arte, para que juntxs pudéssemos bradar a esperança, a equidade e a transformação. Aqui e agora, neste terreiro da concórdia, todxs em tropa e movidxs pela coragem desta heroína Bia a puxar a sua carroça de brincantes, fincamos as raízes deste estrado, urrando em uníssono que a luta das mulheres é nossa. Mesmo atravessando o fogo desta vil artilharia, somos fortes, temos velhas guias. Com Louise e Bia somos alçados ao cume dos sonhos, aprendendo a amar e sermos generosos, a gritar em prol das injustiças, a (RE)EXISTIR.

A ideia da montagem era justamente entender as tramas tão estreitas entre a vida/obra de Bia e as lutas de Louise, procurando alocar os desejos de liberdade e autonomia destas mulheres revolucionárias no coração de um público mais uma vez golpeado pelo Estado, numa diferença temporal de cinquenta anos, como se o duro aprendizado dos anos 1960/1970 não mais ecoasse no nosso tempo.

Na percepção da articulação entre os dois períodos históricos, segui perguntando à nossa interlocutora:

EU: Que conexões existem entre as práticas anarquistas de Louise Michel e as práticas do Teatro-Circo Alegria dos Pobres?

BIA: As bases são as mesmas. O trabalho coletivo em autogestão, solidariedade, ajuda mútua, um trabalho militante na sociedade. O Teatro-Circo fazia parte de um movimento de Teatro Independente, isto é, independente de partido ou qualquer instituição. Ele teve duas sedes próprias e autônomas e fazia apresentações na periferia, junto de outros movimentos para organização da população, autônomos ou ligados à Igreja ou aos sindicatos. Por exemplo, um grupo de estudantes da USP que militava junto à associação dos moradores para conseguir melhorias em uma favela no Rio Pequeno, nos convidou para nos apresentar em um terreno de terra batida, ao ar livre. Neste terreno pretendiam construir uma creche com múltiplas atividades. A luta era junto à Prefeitura de São Paulo e nós fomos fazer a apresentação. Eles queriam mostrar à população da favela, que além de uma creche, poderia existir ali uma grande atividade cultural, no salão, com por exemplo, grupos de teatro, de música, etc. Já havia estado ali, no mesmo terreno, um pessoal com uma criação coletiva sobre o sofrimento da favela, feito pelos estudantes da USP, sem sucesso de público porque os estudantes ficaram dentro de seus carros, olhando pra favela como que amedrontados e o nosso amigo que nos convidou, pediu que subíssemos favela adentro, fazendo divulgação, chamando o público com música, era pastoril, cordel e mamulengo que fazíamos. Nossos músicos e 
toda a moçada do Teatro-Circo, com as roupas da peça, andamos de casa em casa em toda a favela chamando público. Na hora marcada, montamos nosso cenário cheio de telões feitos pelo pessoal da cenografia do Teatro-Circo, e com meia dúzia de pessoas começamos o espetáculo. Foi um dos momentos mais bonitos da nossa peregrinação. O morro foi descendo e praticamente, entrando dentro do cenário. Eles assistiam de todos os lados. Algum tempo depois soubemos que começou ali a construção do salão, feita com a pressão ao prefeito. Essa é a luta em que eu acredito. Quando nos nossos espetáculos de Pour Louise ou A Desejada Virtude da Resistência, nos quatro dias em abril de 2018, as pessoas se dispuseram profundamente interessadas em tudo o que contamos sobre a Louise e a Comuna de Paris, a emoção foi a mesma. Era preciso tocar este impossível chão. O Teatro-Circo era um grupo itinerante, assim como Louise Michel, e uma vez por mês durante os primeiros anos, o grupo se apresentou para os menores infratores das unidades da FEBEM da capital e do interior de São Paulo. Embora o princípio anarquista de rejeitar a existência do estado era uma assertiva do grupo, foi através de uma rebeldia contra o estado, que financiava estas apresentações na FEBEM através da Secretaria de Cultura, o grupo participou deste projeto estadual, que veio a dar origem ao livro Teatro de Militância de Silvana Garcia. Eu recebia uma quantia como monitora, que doava ao Teatro-Circo, uma vez que eu já recebia o meu salário como professora. Este dinheiro foi durante tempos, a fonte para fazermos as peças seguintes, pagarmos as despesas de figurinos, cenários também. As excursões que nos levavam à FEBEM também eram pagas com este dinheiro (ônibus, comida). Quando o projeto terminou, passamos a apresentar nossos espetáculos nas escolas de periferia, onde ganhávamos o suficiente para construir as novas peças. Isto debaixo de uma ditadura ferrenha, no período entre 1974 e 1979.



Figura 2 - Cenas de Pour Louise ou a desejada virtude da resistência, com Beatriz Tragtenberg, Lucila Tragtenberg, Mariana Mayor, Larissa Galvão, Paulinho Brandão e Paulinho Tó. Direção e dramaturgia de Luciana Lyra. Espaço da Cia do Latão, em São Paulo (SP), abril de 2018 Imagens de Morgana Narjara.

Era inevitável ouvir todos aqueles relatos e não identificar o trabalho de Bia como uma ação invariavelmente vinculada às práticas feministas, entendendo feminismo na chave indicada por Marcia Tiburi (2018, p. 23): 
O Feminismo nos ajuda a melhorar o modo como vemos o outro. O direito de ser quem é, de expressar livremente a forma de estar e de aparecer e, sobretudo, de se autocompreender é ao que o feminismo nos leva. A postura autocrítica necessária a toda crítica honesta depende dessa mudança de olhar, que depende, por sua vez, de nossa capacidade de prestar atenção. Essa capacidade não é natural, é constituída em processos de aprendizagem que envolvem a nossa própria construção como pessoas.

\section{Mas restava saber se a própria Bia compreendia assim a sua prática e se está- vamos mais uma vez em confluência de pensamentos. Perguntei:}

\section{EU: Você considera que faz um teatro feminista?}

BIA: Considero. Ao apresentar a figura de Louise Michel dentro de um contexto revolucionário de práticas libertárias, já em 1871, demonstrando a luta pela educação (ela lutou pela educação das meninas, que na época não podiam estudar e eram restritas à educação doméstica) pelos direitos das mulheres, pela audácia de pegar em armas e pelas lutas libertárias nos vinte últimos anos de sua vida, espero ter dado a conhecer à maioria dos jovens, e mesmo ao povo brasileiro, a grandeza desta figura. Sua grande luta foi também pela educação pública de meninas e meninos. Aliás, a Comuna de Paris não é menos desconhecida. Espero também tê-la tornado mais conhecida, apresentando uma opção de organização social e política solidária.

EU: Como foi sua relação com novo texto e direção de Pour Louise? Esta direção/ texto esteve conectada com suas posições políticas? Feministas?

BIA: Sim, minha grande Luciana. Ao nos conhecermos, não precisamos dizer mais do que duas palavras para que nos sentíssemos no mesmo diapasão de uma visão de mundo cooperativa, desprendida de um espírito mercenário, livre e libertária. Quando nos apresentamos, ao ler o seu trabalho de doutorado, espelhei-me em você: eu pesquisando a Louise e você pesquisando as mulheres em Pernambuco, eu desejando um texto poético e você realizando um texto poético, tanto na criação dramatúrgica da peça sobre as mulheres como na direção do espetáculo. Assim, quando lhe perguntei se você faria a dramatização que eu desejava da pesquisa que fiz sobre Louise e a Comuna, você respondeu tranquilamente, e eu aceitei tranquilamente, sim. A minha relação com o novo texto, o texto de Pour Louise ou A Desejada Virtude da Resistência, foi de alívio, porque eu não conseguia fazer como atriz aqueles textos que estavam compilados no texto de Memórias de Louise, e que eu apresentava como leitura dramática. Aqueles trechos eram acadêmicos e não participavam da figura viva, poética, de Louise. Você conseguiu contextualizar a escrita da Louise, inclusive com belos trechos escritos por você, como os monólogos iniciais da peça. A inclusão de músicas feitas especialmente para colocar viva em cena a mulher Louise, foram responsáveis pelo encanto e leveza que trouxeram à peça. Na direção do espetáculo foram muito bem realizadas as intercalações das músicas e dos músicos-atores (personas retiradas da biografia de Louise como em um sonho delirante, a figura de seu avô, das amigas, etc) dialogando com a figura da Louise, que quando se dirigia diretamente ao público, era discursiva, um monólogo. A minha relação com a sua direção foi de grande entendimento, uma vez que você compreendendo a minha dificuldade em realizar muitas movimentações cênicas, elaborou um constante e rápido deslocamento dos músicos-atores, que trouxe a característica de leveza, de graça ao espetáculo, permitindo o transe poético da encenação. Creio que é muito importante conservar esta característica porque embora tenham sido retiradas algumas cenas mais trágicas (como o encontro de Louise com a mãe e quando a mãe de Ferré enlouquecida deixa escapar para o policial que a torturava mentalmente, o endereço do esconderijo de seu filho), conseguimos fazer com que o público gostasse muito do espetáculo, permitindo praticamente, 
mais de uma hora de informações sobre a Comuna e a Louise no debate para o qual ficavam após a peça, devido à sua grande satisfação com ela, neste formato mais leve. Nestes debates pude trazer mais informações, inclusive a discussão sobre a luta feminista. A direção e o texto da peça estiveram conectados com minhas posições políticas. Sempre estive conectada à luta feminista, como você.

Entrar em contato com Bia e sua dimensão Louise Michel intensificou o calibre político de meus trabalhos, ao compreender mais profundamente que apontar motivações por trás de um trabalho de teatro é afinar as conexões entre arte e ideologia, estética e ativismo, polifonia e conscientização social. Desta perspectiva, o teatro que ela estava em busca com o Teatro-circo Alegria dos Pobres, na década de 1970, com o nosso Pour Louise, entre 2016 e 2018, era o que chamo de arte de $f(r) i c ̧ a ̃ o^{11}$, onde as reais intencionalidades da ação artística se tramam às ficções, levando-nos não só um questionamentos, mas também a uma justificação e um reforço ideológico do nosso teatro. Sobre isso que nomeio de processo de politização, Bia ainda respondeu algumas de minhas indagações.

EU: Você acha que o teatro continua sendo uma ferramenta social, de conscientização?

BIA: Claro, o teatro salva! Não é à toa que toda a ditadura persegue o teatro não comercial, de montagens elaboradas artisticamente.

EU: O teatro que não se propõe a questionamentos políticos interessa a quem?

BIA: Todo teatro é político, portanto, aquele que se apresenta como não questionador politicamente, é revelador de um pensamento autoritário de dominação ideológica conservadora. $\mathrm{O}$ teatro que não explicita uma temática política, mas coloca em cena situações sociais que denotam a repressão política e o pensamento autoritário, como por exemplo textos de dramaturgos americanos como Tennesse Williams e os textos de Shakespeare, não são menos políticos e são a grande arte. Um teatro que se explicita nomeadamente político, que eu conheça, é $\mathrm{o}$ teatro anarquista que se propõe a realizar a divulgação das teses anarquistas. E nem por isto é menos artístico, como por exemplo, o trabalho de Dario Fo, e aqui no Brasil, os textos de Pedro Catallo (1900-1969), anarquista histórico ligado ao Centro de Cultura Social em São Paulo (agremiação criadas pelos anarquistas, grande parte foragidos da revolução Espanhola de 1936).

Já se anunciava o crepúsculo e sentia que precisava ir, já começava a esfriar como é de costume em São Paulo, em fins de maio. A querida guerreira Bia também precisava descansar a palavra. Levantei-me. Entretanto, antes de ir, senti que além do longo abraço de companheiras de luta, precisava, como artista, de um último conselho de quem viveu os golpes da jornada, os abismos das guerras e soube manter a fé no futuro.

Investigativa, ainda perguntei:

EU: Vivemos momentos de ódio, intolerância... Como reverter esses sentimentos tão egoístas e covardes? Ódio combate com ódio?

\footnotetext{
11 Termo que deriva da ideia de Artista de f(r)icção, por mim defendida em doutoramento em Artes da Cena (UNICAMP/2011) e pós doutorados (USP/2013 e UFRN/2015). A Artista de $f(r)$ icção opera no entrelugar do real/ficcional, lidando com níveis profundos de si no imaginário cultural, num processo de autoexploração e atrito entre arte/vida pela via da cena performática.
} 
BIA: Aprendi com Mauricio Tragtenberg, a valorizar um pensamento de Espinoza: "Ante os fatos, nem rir, nem chorar, mas compreender". Eu acredito no esclarecimento do ser humano, por isso acredito na luta da resistência, no trabalho de formiga para a transformação, que é diário e permanente. O combate com o ódio só leva à violência, por isto é importante o esclarecimento através de sentimentos, da afeição, da generosidade, da discussão e do diálogo. Eu estou mais para Gandhi do que para Lenin. Gandhi conseguiu a paz pelo convencimento. Lenin lutou contra o poder absoluto e cruel dos czares e em uma revolução sangrenta em 1917, também se portou como um czar, impondo o partido comunista com o seu centralismo democrático em um poder totalitário, eliminou com requintes de crueldade a participação no governo, de todas as forças progressistas. Isto foi feito por ele e por Trotsky, matando os marinheiros de Kronstadt durante dois anos de guerra com eles e eliminando, matando, covardemente em um desfiladeiro, os companheiros anarquistas que retornavam de uma batalha vitoriosa em conjunto com as tropas de Trotsky, contra o exército alemão. Precisamos resistir discutindo, refletindo, explicando. É o trabalho que realizamos no dia a dia que conta como a militância do teatro e o apoio às lutas populares. Eu acredito, como grande parte dos jovens de hoje, nos coletivos que tem surgido em várias áreas (alimentação, teatro, cultura, etc.), em um trabalho de organização em auto-gestão, onde a igualdade, a liberdade, a cooperação são grandes traços libertários.

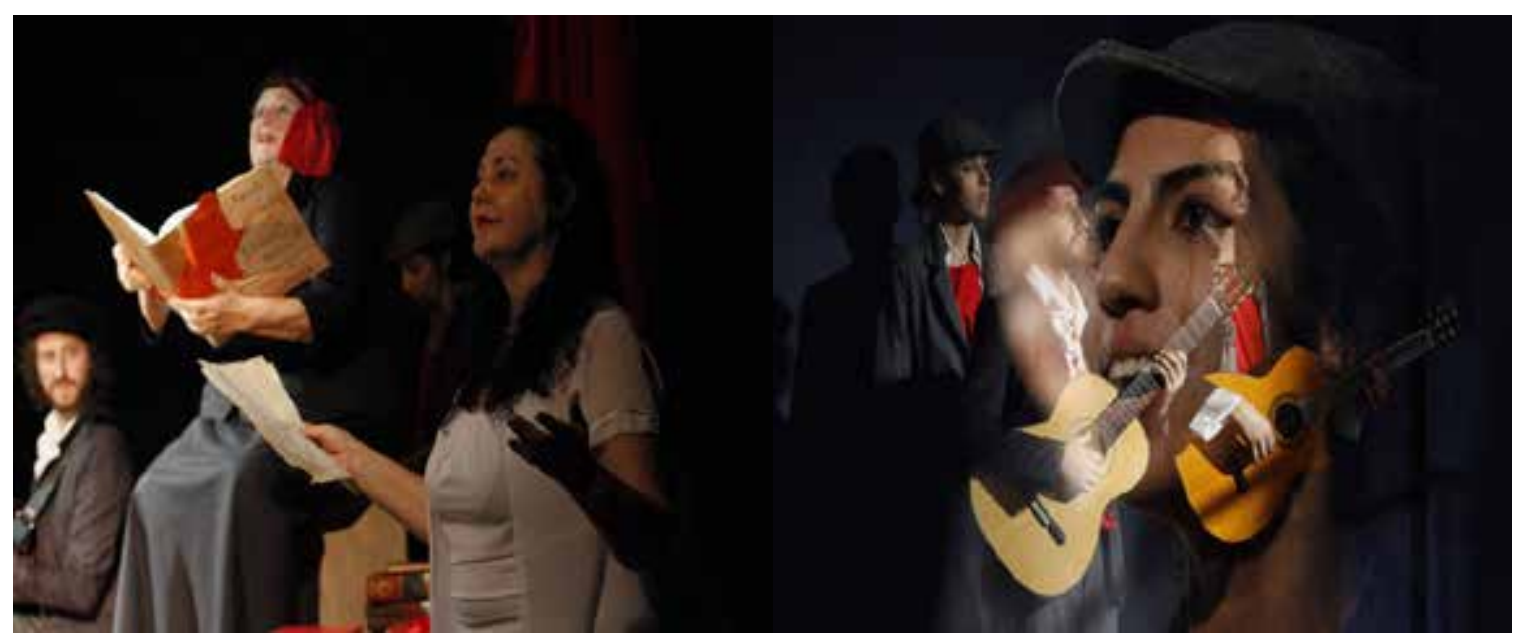

Figura 3 - Cenas de 'Pour Louise ou a desejada virtude da resistência', com Beatriz Tragtenberg, Lucila Tragtenberg, Mariana Mayor, Larissa Galvão, Paulinho Brandão e Paulinho Tó. Direção e dramaturgia de Luciana Lyra. Espaço da Cia. do Latão, em São Paulo-SP, abril de 2018. Imagens de Morgana Narjara.

Ao fim da tarde, um longo abraço era imprescindível. O afeto de quem entrecruza gerações e causas era tudo que restava, além do grito ensurdecedor e do silêncio profundo de duas mulheres que se fitam e depois juntas mergulham os olhos no horizonte, rompendo as amarras, cantando a nova mensagem. Ao sair da casa de Bia, carreguei nos ouvidos as palavras que eu própria escrevi para ela na dramaturgia de Pour Louise. Como um espelho estilhaçado estranhamente sonoro, ecoava continuamente a sua voz no meu embornal.

Louise

O que nos resta é acreditar nos sonhos postos em ação. Aqui neste terreiro da concórdia que é o teatro, nesta praça, sob refletores que são estrelas, decreto minha crença no sonho e na transformação que sonhou minha Louise. Ao menos aqui e quiçá no mundo em breve, concordamos em ser livres e eternos. (Aos músicos/atores) Senhores, façam o tambor ressoar, cantem aos quatro ventos e avancem para outro campo de luta e arte. Avancem!!!

(Lyra, 2017, p. 18) 


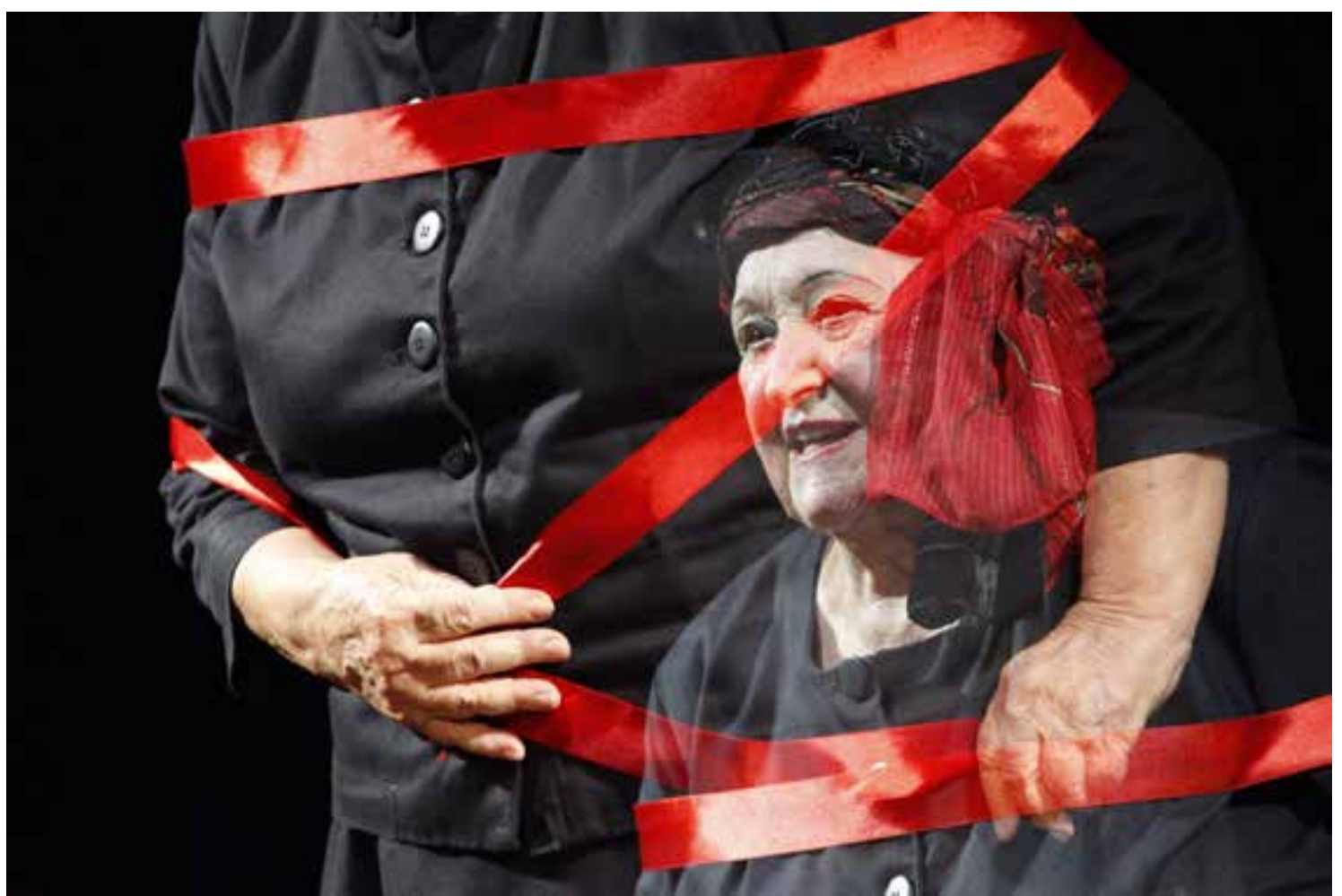

Figura 4 - Cena de 'Pour Louise ou a desejada virtude da resistência', com Beatriz Tragtenberg, sob direção e dramaturgia de Luciana Lyra. Espaço da Cia. do Latão, em São Paulo-SP, abril de 2018. Imagem de Morgana Narjara.

\section{Referências}

BEIJAMIM, Walter. Experiência e Pobreza. In: BENJAMIN, Walter. Obras escolhidas: Magia e técnica, arte e política. São Paulo: Editora Brasiliense, 1987.

BOAL, Augusto. Teatro do oprimido e outras poéticas políticas. Rio de Janeiro: Civilização Brasileira, 2011.

FREINET, C. O método natural. Trad. Franco de Sousa e Teresa Balté. Lisboa: Estampa, 1969.

FREINET, Élise. O itinerário de Cèlestin Freinet. Rio de Janeiro: Livraria Francisco Alves, 1979.

FREIRE, Paulo. Pedagogia do Oprimido. São Paulo: Paz e Terra, 2005.

JÚNIOR, Carlos Moarcir Vedovato. Louise Michel: entre a musa e a metralha (re)leitura da poeta anarquista no Brasil. Revista Non Plus. número 7. São Paulo. Dezembro de 2015, USP, 2015, pp 108-124.

LOURO, Guacira Lopes. Gênero, Sexualidade e Educação: Uma perspectiva pós-estruturalista. Petrópolis-RJ: Vozes, 1997. 
LYRA, Luciana de Fátima Rocha Pereira de. Pour Louise ou a desejada virtude da resistência. São Paulo-SP: texto teatral não publicado, 2017.

Mitodologia em Arte no cultivo do trabalho do ator: Uma experiência de $f(r)$ icção. Natal-RN, 2015. Relatório (Pós-doutorado em Artes Cênicas) - DEART, Universidade Federal do Rio Grande do Norte (UFRN).

MAGALDI, Sábato; VARGAS, Maria Thereza. Cem anos de teatro em São Paulo (18751974). São Paulo: Editora Senac, 2000.

MICHEL, Louise. Cartas a Victor Hugo. Vinhedo/São Paulo: Editora Horizonte, 2005.

RAGO, Margareth. A aventura de contar-se: feminismos, escrita de si e invenções de subjetividade. Campinas-SP: Editora da Unicamp, 2015.

SANTOS, Bárbara; VANUCCl, Alessandra. Laboratório Madalenas - Teatro das Oprimidas. Disponível em: kuringa-barbarasantos.blogspot.com/2010/08/laboratorio-madalena-teatro. Acesso em 21 de outubro de 2018.

TELES, Maria Amélia de Almeida. Breve história do feminismo no Brasil. São Paulo: Editora Brasiliense, 1993.

TIBURI, Marcia. Feminismo em comum para todas, todes e todos. Rio de Janeiro: Editora Rosa dos tempos, 2018.

TRAGTENBERG, Beatriz. Entrevista: Teatro-circo alegria dos pobres e Pour Louise. São Paulo, domicílio da entrevistada, 12 maio de 2018. Diálogos com entrevistada.

Recebido em: 30/09/2018 Aprovado em: 19/10/2018 